\title{
Pengaruh Profitabilitas, Leverage, Dan Pertumbuhan Perusahaan Terhadap Kebijakan Dividen (Pada Sektor Industri Barang Konsumsi Periode 2016-2019)
}

\author{
Erviana Miranti ${ }^{1}$, Mohamad Zulman Hakim ${ }^{2}$, Dirvi Surya Abbas ${ }^{3}$ \\ Universitas Muhammadiyah Tangerang ${ }^{1,2,3}$ \\ Email korespondensi: Ervianam559@gmail.com
}

\begin{abstract}
Abstrak: Penelitian ini bertujuan untuk mencari tahu pengaruh profitabilitas, leverage, dan pertumbuhan perusahaan terhadap kebijakan dividen pada Perusahaan Sektor Industri Barang Konsumsi di Bursa Efek Indonesia periode 2016-2019. Populasi penelitian ini meliputi perusahaan sektor industri barang konsumsi yang terdaftar di Bursa Efek Indonesia (BEI) periode 2016-2019. Teknik pengambilan sampel ditentukan menggunakan metode purposive sampling sehingga diperoleh 76 sampel dari 19 perusahaan. Metode penelitian ini menggunakan analisis Regresi Data Panel. Hasil penelitian ini menunjukkan bahwa terdapat pengaruh variabel profitabilitas dan pertumbuhan perusahaan berpengaruh positif terhadap kebijakan dividen. Sedangkan variabel leverage berpengaruh negative terhadap kebijakan dividen.
\end{abstract}

Kata Kunci : Profitabilitas, Leverage, Pertumbuhan Perusahaan terhadap Kebijakan Dividen

Fenomena yang terjadi pada perusahaan sektor industri barang konsumsi terkait tidak membagikan dividen pada perusahaan sektor industri barang konsumsi sub sektor makanan dan minuman dibahas pada salah satu media yang memberitakan mengenai tidak membagikan dividen. PT Sekar Bumi Tbk (SKBM) membukukan 10\% perolehan laba bersihnya selama periode 2018 yaitu Rp 15,95 miliar sebagi laba ditahan. Dalam keterbukaan informasi di BEl, direksi SKBM menyebut keputusan tersebut berdasarkan keputusan Rapat Umum Pemegang Saham Tahunan (RUPST). Oleh karena itu, perseroan tidak membagikan dividen kepada pemegang saham (IDN Financials, 2019).

Penelitian yang dilakukan Moradi dkk (2010), menunjukkan profitabilitas berpengaruh positif terhadap kebijakan dividen. Hasil yang berbeda ditemukan dalam penelitian (Nuringsih, 2005) menyebutkan bahwa profitabilitas berpengaruh negatif signifikan terhadap kebijakan dividen. Sedangkan dalam penelitian Damayanti dan Achyani (2006) dan Raissa (2011) yang menyatakan bahwa profitabilitas tidak berpegaruh terhadap kebijakan dividen.Dalam penelitian yang dilakukan oleh Sunarya (2013), Mawarni dan Ratnadi (2014) menjelaskan bahwa leverage berpengaruh negatif terhadap kebijakan dividen. Sedangkan penelitian dari Sari dan Sudjarni (2015) menunjukkan bahwa leverage berpengaruh positif terhadap kebijakann dividen. Namun berbanding dengan hasil Farisah (2015) yang menyatakan bahwa leverage tidak berpengaruh terhadap kebijakan dividen.Pertumbuhan perusahaan memliki pengaruh positif terhadap kebijakan dividen (Difah,2013). Namun bertentangan 
dengan hasil Fira (2009), Jannati (2010), dan Ita (2013) menyatakan bahwa pertmbuhan perusahaan berpengaruh negatif terhadap kebijakan dividen.

\section{METODE}

Penelitian ini dilakukan berdasarkan informasi yang didapatkan melalui Bursa Efek Indonesia. Populasi penelitian ini adalah perusahaan manufaktur sektor industri barang konsumsi yang tercatat di Bursa Efek Indonesia dari tahun 2017 sampai 2019. Penelitian ini menggunakan metode purposive sampling dalam pengambilan sampel. Pengambilan sampel pada penelitian ini harus memenuhi kriteria sebagai berikut:

- Perusahaan sektor industri barang konsumsi yang terdaftar di Bursa Efek Indonesia periode 2016-2019

- Perusahaan sektor industri barang konsumsi yang tidak konsisten menerbitkan laporan keuangan periode 2016-2019

- Perusahaan sektor industri barang konsumsi yang mengalami kerugian periode 2016-2019

- Perusahaan sektor industri barang konsumsi yang tidak membagikan dividen selama periode 2016-2019

Dalam penelitian ini menggunakan analisis regresi data panel dengan software pengolahan data Eviews 9.0. Berikut adalah metode analisis data yang digunakan:

1. Analisis Statistik Deskriptif

Menurut Priyanto (2008) dan Syaputri (2019) menjelaskan bahwa analisis deskriptif menggambarkan tentang ringkasan data-data penelitian seperti mean, standard deviasi, variasi, modus, dan sebagainya.

\section{Estimasi Regresi Data Panel}

a. Common Effect Model

Model yang mengkombinasikan data time series dan cross section. Dengan hanya menggabungkan kedua jenis data tersebut, maka dapat digunakan metode Ordinal Least Square (OLS) atau teknik kuadrat terkecil untuk mengetimasi model data panel (Chistiawati, 2017).

b. Fixed Effect Model

Model ini mengansumsikan adanya perbedaan intersep antar individu namun intersepnya sama antar waktu, dan koefisien regresi (slope) tetap antar individu waktu. Teknik model fixed effect mengestimasi data panel dengan menggunakan variabel dummy untuk menangkap adanya perbedaan intersep. Model ini disebut teknik Least Square Dummy Variabel (Christiawati, 2017).

c. Random Effect Model

Pada model Random Effect perbedaan intersep diakomodasi oleh eror terms antar perusahaan. Keuntungan menggunakan model random effect yakni menghilangkan heteroskedastisitas. Model ini 
disebut dengan Error Component Model (ECM) atau teknik Generalized Least Square (GLS) (Christiawati, 2017).

\section{Teknik Pemilihan Model Regresi Data Panel}

a. Uji Chow

Uji chow digunakan untuk menentukan model yang tepat antara model common effect dengan hipotesis sebagai berikut :

$\mathrm{H}_{0}$ : model common effect jika profitabilitas cross-section $\mathrm{F}$ dan cross-section chi-square $>\alpha(0,05)$

$\mathrm{H}_{\mathrm{a}}$ : model fixed effect jika profitabilitas cross-section $\mathrm{F}$ dan crosssection chi-square $<\alpha(0,05)$

b. Uji Hausman

Uji hausman digunakan untuk menentukan model yang tepat antara model fixed effect atau random effect dengan hipotesis sebagai berikut:

$\mathrm{H}_{0}$ : model random effect jika profitabilitas cross-section random $>\alpha$ $(0,05)$

$\mathrm{H}_{\mathrm{a}}$ : model fixed effect jika profitabilitas cross-section random $<\alpha$ $(0,05)$

c. Uji Lagrange Multiplier

Uji lagrange multiplier digunakan untuk menentukan model yang tepat antara model random effect atau common effect dengan hipotesis sebagai berikut :

$\mathrm{H}_{0}$ : model common effect jika profitabilitas cross-section breuschpagan $>\alpha(0,005)$

$\mathrm{H}_{\mathrm{a}}$ : model random effect jika profitabilitas cross-section breuschpagan $<\alpha(0,05)$

4. Uji Asumsi Klasik

Diperlukan uji aumsi klasik apabila model regresi yang digunakan dalam bentuk CEM atau FEM. Sebaliknya apabila persamaan regresi lebih layak menggunakan REM maka tidak perlu dilakukan uji asumsi klasik.

a. Uji Multikolinearitas

Uji multikolinearitas digunakan untuk menguji model regresi, apakah ada koreksi antar variabel independen dengan hipotesis sebagai berikut:

$\mathrm{H}_{0}$ : terjadi multikolinearitas jika nilai koefisien korelasi $>0,8$

$\mathrm{H}_{\mathrm{a}}$ : tidak terjadi multikolinearitas jik nilai koefisien korelasi $<0,8$

b. Uji Heteroskedastisitas

Uji heteroskedastisitas digunakan untuk menguji perbedaan variance dalam model regresi dari residual satu pengamatan ke pengamatan lain dengan hipotesis sebagai berikut :

$\mathrm{H}_{0}$ : tidak terjadi heteroskedastisitas jika $\mathrm{p}$-value $>0,05$

$\mathrm{H}_{\mathrm{a}}$ : terjadi heteroskedastisitas jika $\mathrm{p}$-value $<0,05$

5. Uji Hipotesis
a. Uji F 
Uji $F$ digunakan untuk menunjukkan apakah variabel independen secara bersama-sama mempunyai pengaruh terhadap variabel dependen dengan hipotesis sebagai berikut:

a) Berdasarkan perhitungan antara F-statistik dengan $F$ table $\mathrm{H}_{0}$ : nilai F-statistik < $\mathrm{F}$ Table

$\mathrm{H}_{\mathrm{a}}$ : nilai F-statistik > F Tabel

b) Berdasarkan profitabilitas

b. Uji $R^{2}$

$\mathrm{H}_{0}$ : nilai Prob (F-statistik) $>\alpha(0,05)$

$\mathrm{H}_{\mathrm{a}}$ : nilai Prob (F-statistik) $<\alpha(0,05)$

Uji $R^{2}$ digunakan untuk memprediksi seberapa besar kontribusi pengaruh variabel independen terhadap variabel dependen. Nilai Rsquared berada antara 0 sampai 1 dengan penjelasan sebagai berikut:
a) Nilai R-square harus berkisar 0 sampai 1
b) Jika nilai R-squared sama dengan 1, berarti naik atau turunnya variabel dependen $100 \%$ dipengaruhi oleh variabel independen
c) Jika nilai R-squared sama dengan 0 , berarti tidak ada hubungan sama sekali antara variabel independen terhadap variabel dependen

c. Uji t

Uji t digunakan untuk mengetahui signifikan tidaknya pengaruh dari variabel independen terhadap variabel dependen dengan hipotesis sebagai berikut :
$\mathrm{H}_{0}$ : nilai t-statistik < t table
$\mathrm{H}_{\mathrm{a}}$ : nilai t-statistik $>\mathrm{t}$ table
b) Berdasarkan probability
$\mathrm{H}_{0}$ : nilai Prob. $>\alpha(0,05)$
$\mathrm{H}_{\mathrm{a}}$ : nilai Prob. $<\alpha(0,05)$

a) Berdasarkan perbandingan antara t-statistik dengan t table :

6. Analisis Regresi Data Panel

Analisis ini digunakan untuk mengetahui arah hubungan antara variabel independen dengan variabel dependen dengan persamaan sebagai berikut :

Keterangan :

$$
\text { DPR }=\alpha+\beta_{1} \text { PROFT }+\beta_{2} \text { LEV }+\beta_{3} \text { GRWT }+e
$$

$\begin{array}{ll}\text { DPR } & \text { : Kebijakan Dividen } \\ \text { A } & \text { : Konstanta } \\ \beta & : \text { Koefisien Regresi } \\ \text { PROFT } & : \text { Profitabilitas } \\ \text { LEV } & : \text { Leverage } \\ \text { GWRT } & : \text { Pertumbuhan Perusahaan } \\ \text { E } & : \text { Eror }\end{array}$


HASIL

Tabel 1 . Analisis Statistic Deskriptif

Date: $01 / 06 / 2$

Time: $14: 45$

Sample: 20162019

\begin{tabular}{lcccc}
\hline \hline & DPR & ROA & DER & GROWTH \\
\hline \hline Mean & 0.530422 & 0.153101 & 0.769230 & 0.100629 \\
Median & 0.408087 & 0.109573 & 0.513730 & 0.092177 \\
Maximum & 5.235785 & 0.920997 & 2.909487 & 0.656155 \\
Minimum & 0.011505 & 0.000866 & 0.100180 & -0.998060 \\
Std. Dev. & 0.622206 & 0.148953 & 0.682265 & 0.228637 \\
Skewness & 5.818751 & 2.448915 & 1.485675 & -2.244638 \\
Kurtosis & 44.31565 & 11.14024 & 4.460182 & 14.46010 \\
Jarque-Bera & 5834.312 & 285.7988 & 34.70999 & 479.7104 \\
Probability & 0.000000 & 0.000000 & 0.000000 & 0.000000 \\
Sum & 40.31208 & 11.63570 & 58.46147 & 7.647839 \\
Sum Sq. & & & & \\
Dev. & 29.03549 & 1.664026 & 34.91145 & 3.920624 \\
Observations & 76 & 76 & 76 & 76
\end{tabular}

Nilai Mean terbesar dialami oleh variabel DER yaitu sebesar 0.769230 sementara variabel GROWTH memiliki nilai Mean terkecil yaitu 0.0100629. Nilai Median terbesar dialami oleh variabel DER yaitu sebesar 0.513730 sementara variabel GROWTH memiliki nilai Median terkecil yaitu 0.092177. Nilai Maximum terbesar dialami oleh variabel DPR yaitu sebesar 5.235785 sementara variabel GROWTH memiliki nilai Maximum terkecil yaitu 0.656155. Nilai Minimum terbesar dialami oleh variabel DER yaitu 0.100180 sementara variabel GROWTH memiliki nilai Minimum terkecil yaitu -0.998060. Nilai Standar Deviasi terbesar dialami oleh variabel DER yaitu sebesar 0.682265 yang berarti bahwa variabel bahwa variabel DER memiliki tingkat risiko yang lebih tinggi mengalami perubahan dibandingkan dengan variabel-variabel yang lain selama periode penelitian. Sementara variabel ROA mempunyai tingkat risiko yang paling rendah, yaitu sebesar 0.148 .953 . Hal ini menunjukkan bahwa variabel ROA selama periode penelitian mengalami perubahan yang tidak terlalu fluktuatif.Nilai Skewness yang memiliki nilai di atas 0 (nol) yaitu variabel DPR, ROA dan DER yang berarti bahwa asimetri distribusi data di sekitar mean tidak normal, sedangkan variabel GROWTH memiliki nilai di sekitaran 0 (nol) yang berarti bahwa asimetri distribusi data di sekitar mean bersifat normal. Nilai Kurtosis untuk variabel DPR, ROA, DER dan GROWTH memiliki nilai Kurtosis lebih dari 3 yang berarti bahwa 
ketinggian distribusi data tidak normal. Jarque-Bera adalah uji statistik untuk mengetahui apakah data berdistribusi normal. Uji ini mengukur perbedaan skewness dan kurtosis data dan dibandingkan dengan apabila data nya bersifat normal. Dengan $H O$ pada data berdistribusi normal, uji Jarque-Bera didistribusi dengan $x 2$ dengan derajat bebas (degree of freedom) sebesar 2. Probability menunjukkan kemungkinan nilai JarqueBera melebihi (dalam nilai absolut) nilai terobservasi di bawah hipotesis nol. Nilai probabilitas yang kecil cenderung mengarahkan pada penolakan hipotesis nol distribusi normal.

Table 2 . Uji Chow

Redundant Fixed Effects Tests

Equation: EQ01

Test cross-section fixed effects

\begin{tabular}{lrrr}
\hline \hline Effects Test & Statistic & d.f. & Prob. \\
\hline \hline Cross-section F & 1.659007 & $(18,54)$ & 0.0777 \\
Cross-section Chi-square & 33.454446 & 18 & 0.0147 \\
\hline \hline
\end{tabular}

Berdasarkan hasil perhitungan di atas, nilai Probabilitas Cross-section $F$ dan Cross-section Chi-square > 0,05. Maka dapat disimpulkan bahwa Common Effect Model (CEM) lebih layak digunakan dibandingkan Fixed Effect Model (FEM).

\section{Table 3 . Uji Hausman}

Correlated Random Effects - Hausman Test

Equation: EQ01

Test cross-section random effects

Ber dasarkan hasil

\begin{tabular}{|c|c|c|c|c|}
\hline Test Summary & $\begin{array}{l}\text { Chi-Sq. } \\
\text { Statistic }\end{array}$ & $\begin{array}{r}\text { Chi-Sq. } \\
\text { d.f. }\end{array}$ & Prob. & $\begin{array}{l}\text { perhitunga } \\
\mathrm{n} \text { di atas, }\end{array}$ \\
\hline Cross-section random & 4.252955 & 3 & 0.2354 & robabilit \\
\hline
\end{tabular}

section random sebesar 0,2354 > 0,05. Maka dapat disimpulkan bahwa Random Effect Model (REM) lebih layak digunakan dibandingkan Fixed Effect Model (FEM).

Table 4 . Uji Lagrange Multiplier

Lagrange Multiplier Tests for Random Effects

Null hypotheses: No effects

Alternative hypotheses: Two-sided (Breusch-Pagan) and 
one-sided

(all others) alternatives

\begin{tabular}{lcccc}
\hline \hline & \multicolumn{3}{c}{ Test Hypothesis } \\
& Cross-section & Time & Both \\
\hline \hline Breusch-Pagan & 0.763459 & 0.658377 & 1.421836 \\
& $(0.0022)$ & $(0.4171)$ & $(0.2331)$ \\
& & & \\
Honda & 0.873762 & 0.811404 & 0.044093 \\
& $(0.1911)$ & -- & $(0.4824)$ \\
King-Wu & & - & - \\
& 0.873762 & 0.811404 & 0.420964 \\
& $(0.1911)$ & -- & -- \\
Standardized Honda & 1.249453 & 0.543323 & 3.474478 \\
& $(0.1057)$ & -- & -- \\
Standardized King-Wu & 1.249453 & 0.543323 & 3.119971 \\
Gourierioux, et al. ${ }^{*}$ & $(0.1057)$ & -- & -- \\
& -- & -- & 0.763459 \\
& & & $(>=0.10)$ \\
\hline \hline
\end{tabular}

*Mixed chi-square asymptotic critical values:

$\begin{array}{rr}1 \% & 7.289 \\ 5 \% & 4.321 \\ 10 \% & 2.952\end{array}$

Berdasarkan hasil perhitungan di atas nilai Probabilitas Cross-section Breusch Pagan < 0,05. Maka dapat disimpulkan bahwa Random Effect Model (REM) lebih layak digunakan dibandingkan Common Effect Model (CEM).

Tabel 5 . Kesimpulan Model Regresi

\begin{tabular}{|c|l|c|c|}
\hline No & \multicolumn{1}{|c|}{ Metode } & Penguji & Hasil \\
\hline 1 & Uji Chow & CEM vs FEM & CEM \\
\hline 2 & Uji Hausman & REM vs FEM & REM \\
\hline 3 & Uji Lagrange Multiplier & CEM vs REM & REM \\
\hline
\end{tabular}

Berdasarkan hasil ke tiga pengujian yang sudah dilakukan maka dapat disimpulkan bahwa Model Regresi Data Panel yang akan digunakan 
dalam uji hipotesis dan persamaan Regresi Data Panel adalah model Random Effect Model (REM).

Table 6 . Hasil Random Effect Model (REM)

Dependent Variable: DPR

Method: Panel EGLS (Cross-section random effects)

Date: 01/06/21 Time: 17:07

Sample: 20162019

Periods included: 4

Cross-sections included: 19

Total panel (balanced) observations: 76

Swamy and Arora estimator of component variances






\begin{tabular}{lcr} 
& 0.4099 Mean dependent & 0.53042 \\
R-squared & 98 var & 2 \\
Sum squared & $17.131 \quad$ Durbin-Watson & 1.38707 \\
resid & 00stat & 1 \\
\hline \hline
\end{tabular}

Pada output di atas menunjukkan bahwa nilai F-statistic sebesar 17,52115 sementara F Tabel dengan tingkat $\alpha=5 \%$, df1 $(\mathrm{k}-1)=3$ dan df2 $(\mathrm{n}-\mathrm{k})=72$ didapat nilai $\mathrm{F}$ Tabel sebesar 2,73. Dengan demikian F-statistic $(17,52115)>$ F Tabel $(2,73)$ dan nilai Prob (F-statistic) $0,000000<0,05$. Maka dapat disimpulkan bahwa $\mathrm{Ha}$ diterima, maka dengan demikian dapat disimpulkan bahwa variabel-variabel independen dalam penelitian ini yang terdiri dari ROA, DER dan GROWTH secara bersama-sama memiliki pengaruh terhadap DPR.

Pada output di atas menunjukkan bahwa nilai Adjusted R-Squared sebesar 0,397897 artinya bahwa variasi perubahan naik turunnya DPR dapat dijelaskan oleh ROA, DER dan GROWTH sebesar 39,7\% sementara sisanya yaitu $60,3 \%$ dijelaskan oleh variabel-variabel lain yang tidak diteliti dalam penelitian ini.

Nilai t-Statistic ROA sebesar 2.784183 sementara $t$ Tabel dengan tingkat $\alpha=5 \%$, df $(n-k)=72$ didapat nilai $t$ Tabel sebesar 1,99346. Dengan demikian t-Statistic ROA (2.748183) > t Tabel $(1,99346)$ dan nilai Prob $0,0076<0,05$. Maka dapat disimpulkan bahwa variabel ROA dalam penelitian ini memiliki pengaruh terhadap DER.

Nilai t-Statistic DER sebesar 1.591480 sementara t Tabel dengan tingkat $\alpha=5 \%$, df $(\mathrm{n}-\mathrm{k})=72$ didapat nilai $\mathrm{t}$ Tabel sebesar 1,99346. Dengan demikian t-Statistic DER (1.591480) > t Tabel $(1,99346)$ dan nilai Prob 0,1159 > 0,05. Maka dapat disimpulkan bahwa variabel DER dalam penelitian ini tidak memiliki pengaruh terhadap DPR.

Nilai t-Statistic GROWTH sebesar 6.868561 sementara t Tabel dengan tingkat $\alpha=5 \%$, df $(n-k)=72$ didapat nilai t Tabel sebesar 1,99346. Dengan demikian t-Statistic GROWTH $(6.868561)<\mathrm{t}$ Tabel $(1,99346)$ dan nilai Prob $0,0000<0,05$. Maka dapat disimpulkan bahwa variabel GROWTH dalam penelitian ini memiliki pengaruh terhadap DPR.

\section{PEMBAHASAN}

Berdasarkan hasil Random Effect Model (REM) dapat diketahui bahwa persamaan regresi data panel adalah sebagai berikut :

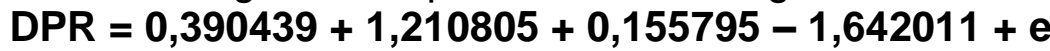

Nilai Konstanta sebesar 0,390439 menunjukkan bahwa jika variabel independen tidak ada atau bernilai 0 maka nilai kebijakan dividen sebesar 0,390439. Nilai Koefisien Regresi Profitabilitas sebesar 1,210805 menunjukkan bahwa setiap kenaikan Profitabilitas sebesar 1\% akan menyebabkan kenaikan kebijakan dividen sebesar 1,210805. Nilai Koefisien Regresi Leverage sebesar 0,155795 menunjukkan bahwa setiap kenaikan Leverage sebesar 1\% akan menyebabkan kenaikan kebijakan dividen sebesar 0,155795. Nilai Koefisien Regresi Pertumbuhan 
Perusahaan sebesar -1,642011 menunjukkan bahwa setiap kenaikan pertumbuhan perusahaan sebesar $1 \%$ akan menyebabkan penurunan kebijakan dividen sebesar -1,642011.

Penelitian ini menggunakan variabel dependen yaitu kebijakan dividend dan variabel independen yaitu profitabilitas, leverage, dan pertumbuhan perusahaan. Objek pada penelitian ini merupakan sektor industri barang konsumsi yang terdaftar di Bursa Efek Indonesia periode 2016-2019. Penambilan data hanya perusahaan yang membagikan dividennya tiap tahun.

\section{Interpretasi Hasil}

Profitabilitas dengan nilai koefisien 1,210805 dan nilai Prob 0,0076 < a menunjukkan bahwa $H_{1}$ diterima, maka kesimpulannya adalah profitabilitas berpengaruh positif dan signifikan terhadap kebijakan dividen. Hasil penelitian ini sesuai dengan penelitian yang dilakukan oleh Nurhayati, 2013 yang menyatakan bahwa profitabilitas berpengaruh positif terhadap kebijakan dividen.

Leverage dengan nilai koefisien 0,155795 dan nilai Prob 0,1159 $>\alpha$ menunjukkan bahwa $H 2$ ditolak, maka kesimpulannya adalah leverage berpengaruh positif dan signifikan terhadap kebijakan dividen. Hasil penelitian ini sesuai dengan penelitian yang dilakukan oleh Sari dan Sudjarni, 2015 yang menyatakan bahwa leverage berpengaruh positif terhadap kebijakan dividen.

Pertumbuhan Perusahaan dengan nilai koefisien -1,642011 dan nilai Prob $0,0000<\alpha$ menunjukkan bahwa $H 3$ diterima, maka kesimpulannya adalah pertumbuhan perusahaan berpengaruh negatif terhadap kebijakan dividen. Hasil penelitian ini sesuai dengan penelitian yang dilakukan oleh Fira (2009), Jannati (2010 dan Ita (2013) yang menyatakan bahwa pertumbuhan perusahaan berpengaruh negatif terhadap struktur modal.

\section{Kesimpulan}

Berdasarkan hasil penelitian, maka dapat ditarik kesimpulan sebagai berikut:

1. Secara simultan (Uji F) variabel profitabilitas, leverage, dan pertumbuhan perusahaan secara bersama-sama memiliki pengaruh terhadap kebijakan dividen.

2. Secara parsial $\left(U_{j i} t\right)$ variabel profitabilitas dan pertumbuhan perusahaan berpengaruh terhadap kebijakan dividen, sedangkan Saran variabel leverage tidak berpengaruh terhadap kebijakan dividen.

Berdasarkan hasil penelitian, terdapat beberapa saran untuk perbaikan penelitian selanjutnya sebagai berikut :

1. Bagi pihak manajemen perusahaan sangat diharapkan agar lebih memperhatikan pembagian dividen kepada para pemegang saham. Hal ini bertujuan untuk bias menarik pihak investor berinvestasi pada perusahaan ketika perusahaan mengalami kesulitan dana. 
2. Untuk penelitian selanjutnya, penelitian dapat dikembangkan dengan menambahkan variabel lain yang dapat digunakan untuk mengukur kebijakan dividen yang dilakukan oleh perusahaan serta dapat menambahkan periode waktu penelitian.

\section{DAFTAR PUSTAKA}

Yudiana, I., \& Yadnyana, I. (2016). Pengaruh Kepemilikan Manajerial, Leverage, Investment Opportunity Set Dan Profitabilitas Pada Kebijakan Dividen Perusahaan Manufaktur. E-Jurnal Akuntansi, 15(1), 111-141. $\leftarrow$ JURNAL ILMIAH

Dewi, D. M. (2016). Pengaruh Likuiditas, Leverage, Ukuran Perusahaan Terhadap Kebijakan Dividen Tunai Dengan Profitabilitas Sebagai Variabel Intervening. Jurnal Bisnis Dan Ekonomi (JBE), 23(1), 12-19. $\leftarrow$ JURNAL ILMIAH

Muslih, M., \& Husin, E. R. (2019). KEBIJAKAN DIVIDEN (Studi Empiris pada Perusahaan Sektor Industri Barang Konsumsi yang terdaftar di Bursa Efek Indonesia Periode 2013-2017). Aksara Public, 3. $\leftarrow$ JURNAL ILMIAH

Purnama Sari, N., \& Budiasih, I. (2016). Pengaruh Kepemilikan Managerial, Kepemilikan Institusional, Free Cash Flow Dan Profitabilitas Pada Kebijakan Dividen. E-Jurnal Akuntansi, 15(3), 2439-2466. $\leftarrow$ JURNAL ILMIAH

Putu, N., Devi, Y., Made, N., \& Erawati, A. (2014). Pengaruh Kepemilikan Manajerial, Leverage, Dan Ukuran Perusahaan Pada Kebijakan Dividen Perusahaan Manufaktur. Jurnal Akuntansi Universitas Udayana, 93, 2302-8556. $\leftarrow$ JURNAL ILMIAH

Setiawati, L. W., \& Yesisca, L. (2016). Analisis Pengaruh Pertumbuhan Perusahaan, Kebijakan Utang, Collateralizable Assets, Dan Ukuran Perusahaan Terhadap Kebijakan Dividen Pada Perusahaan Manufaktur Yang Terdaftar Di Bursa Efek Indonesia Periode 20122014. Jurnal Akuntansi, 10(1), 52-82. $\leftarrow$ JURNAL ILMIAH

Sari, M. R., Oemar, A., \& Andini, R. (2016). Pengaruh pertumbuhan perusahaan, ukuran perusahaan, earning per share, current ratio, return on equity dan debt equity ratio terhadap kebijakan dividen. Journal Of Accounting, 2(2), 1-19. $\leftarrow$ JURNAL ILMIAH

Debi Monika, N. G. A. P., \& Sudjarni, L. K. (2017). Pengaruh Likuiditas, Profitabilitas Dan Leverage Terhadap Kebijakan Dividen Pada Perusahaan Manufaktur Di Bursa Efek Indonesia. E-Jurnal Manajemen Universitas Udayana, 7(2), 905. $\leftarrow$ JURNAL ILMIAH

Idawati, I., \& Sudiartha, G. (2014). Pengaruh Profitabilitas, Likuiditas, Ukuran Perusahaanterhadap Kebijakan Deviden Perusahaan Manufaktur Di Bei. E-Jurnal Manajemen Universitas Udayana, 3(6), 255276. $\leftarrow$ JURNAL ILMIAH

Wahyuliza, S., \& Fahyani, R. (2019). Pengaruh Pertumbuhan Perusahaan, Ukuran Perusahaan, Struktur Modal Dan Return on Equity Terhadap Kebijakan Dividen Pada Perusahaan Manufaktur Yang Terdaftar Di Bursa Efek Indonesia. Jurnal Benefita, 1(1), 78. $\leftarrow$ JURNAL ILMIAH 
Ratnasari, P. S. P., \& Purnawati, N. K. (2019). Pengaruh Profitabilitas, Likuiditas, Tingkat Pertumbuhan Perusahaan Dan Leverage Terhadap Kebijakan Dividen. E-Jurnal Manajemen Universitas Udayana, 8(10), 6179. $\leftarrow$ JURNAL ILMIAH 